\title{
Environmental Concern in Managing Halal Food Supply Chain
}

\author{
${ }^{1}$ Mohd Nizam Ab Rahman, \\ ${ }^{1}$ Malihe Manzouri and ${ }^{2}$ Che Romawati Che Mohd Zain \\ ${ }^{1}$ Department of Mechanical and Materials Engineering, \\ Faculty of Engineering and Built Environment, National University of Malaysia, Malaysia \\ ${ }^{2}$ Graduate School of Management, University Putra Malaysia, 43400 UPM Serdang, Selangor, Malaysia
}

Received 2012-10-26, Revised 2012-12-03; Accepted 2013-06-24

\begin{abstract}
Nowadays environmental issues persuade companies to pursue conditions whereby the needs of the present are met without compromising the resources of future generations. So, implementing green rules and regulations gain more and more attentions. In spite of benefits of implementing green practices, many companies are not understood why they should invest on it. Hence, the aim of this study is to examine what drivers encourage companies to move towards implementing green practices in their supply chains. To achieve the objectives of this study a survey was designed and distributed to 300 halal food companies in Malaysia. A total of 61 usable replies were received. The results of this study revealed that performance and quality improvement, waste and cost reduction are the important drivers of implementing Green Supply Chain (GSC) practices in the halal food companies. It is interesting that having ISO 14000 certificates are reported as the least important driver of implementing GSC practices among these companies. Therefore, it can be concluded that internal benefits mostly motivate halal food companies to implement GSC practices. Since there is little documentation regarding the application of GSC practices in the halal food industries, understanding these issues is identified as a gap in the existing literature.
\end{abstract}

Keywords: Green Supply Chain, Drivers to Implement, Halal Food Industries

\section{INTRODUCTION}

Today global and local environmental problems face companies a new challenging issue which is known as natural environment (Ismail, 2010; Kumaran et al., 2008). Beamon (1999) believed that sourcing, manufacturing and logistics companies are the main cause of these problems. Often these companies are forced by internal or external pressure to decrease their environmental damages. Customers demand, environmental societies, workers and not for profit groups are the common pressures on companies to move towards green practices while doing their business
(Vijaya et al., 2009; Saridogan, 2012). Vachon and Klassen (2006) revealed that the environmentallyfriendly image of products, processes, systems and technologies is portrayed by green concept. Since implementing green practices is subjected to the suppliers and even customers, it cannot be completed, unless it is implemented across the whole supply chain. Rao (2002) highlighted that many companies known Green Supply Chain (GSC) as screening suppliers for their environmental performance and doing business with only suppliers that meet environmental regulations. Sarkis (1998) exposed that driving forces of GSC implementation are much more than this understanding.

Corresponding Author: Mohd Nizam Ab Rahman, Department of Mechanical and Materials Engineering,

Faculty of Engineering and Built Environment, National University of Malaysia, Malaysia 
Table 1. Drivers to

\begin{tabular}{ll}
\hline Drivers & Authors \\
\hline Regulation & (Alvarez-Gil et al., 2007; Kassinis and Vafeas, 2006; Ravi et al., \\
Customer pressures & 2005; Simpson and Power, 2005; Jorgensen et al., 2007) \\
Benefits & (Alvarez-Gil et al., 2007; Rao, 2006; Simpson and Power, 2005) \\
Social responsibility & (Rao, 2006; Williamson et al., 2006) \\
Community pressures & (Simpson and Power, 2005) \\
Competition & (Kassinis and Vafeas, 2006; Lefebvre et al., 2003) \\
Supplier and employee pressures & (Rhee and Lee, 2003) \\
collaboration with suppliers & (Alvarez-Gil et al., 2007) \\
& (Vachon, 2007; Zhu et al., 2007b; \\
ISO 14001 certification & Zhu et al., 2003; 2008; Paulraj, 2009) \\
& (Vachon, 2007; Zhu et al., 2007a; \\
Reusing and recycling materials and packaging & Zhu et al., 2003 2008; Rao and Holt, 2005) \\
& (Paulraj, 2009; Holt and Ghobadian, 2009; Rao and Holt, 2005) \\
\hline
\end{tabular}

GSC concept has grown from early 1990s with emerging corporate environmental management and environmentally conscious manufacturing strategy (Diabat and Govindan, 2011). It includes many sources such as purchasing, marketing, distribution, logistics and operation management (Rao, 2002). Beamon (1999) defined GSC as "the extension of the traditional supply chains to include activities that aims at minimizing environmental impacts of a product throughout its entire life cycle, such as green design, resource saving, harmful material reduction and product recycle or reuse."Traditionally Supply Chain (SC) defined as "a set of three or more entities directly involved in the upstream or downstream flows of products, services, finances and/or information from a source to a customer" (Mentzer et al., 2001; Manzouri et al., 2011). It is relied on constant input of virgin natural resources and unlimited environmental capacity for assimilation of wastes (Geyer and Jackson, 2004). GSC includes reuse, remanufacturing and/or recycling of products and materials into the traditional forward supply chain (Wells and Seitz, 2005).

Often GSC drivers are defined as inducements that motivate companies to adopt new approaches which generally emanate from pressures of external and internal stakeholders. Reviewing the related literature revealed that numerous drivers motivated companies to adapt green practices (Table 1). The important drivers are known as regulation, customer pressures, benefits, social responsibility, community pressures, competition and supplier and employee pressures. Although it is assumed that these drivers have significant effect on GSC implementation, some other studies found no significant effect. For instance, there is not significant relationship between regulations and external pressures on the green purchasing (Bowen et al., 2001; Zhu et al., 2007b).
Although GSC is becoming a popular practice for environment and performance improvement, halal food companies are still not certain of the cost of its implementation and the likely tangible and intangible benefits they may achieve. Most of these companies fear that implementing GSC in their companies is costly and time consuming. Hence, it is very important to identify which drivers can motivate halal food companies in implementing GSC.

Halal food industries are very important for Malaysians as $60 \%$ of its population are Muslim and many Halal manufacturing are dominated by nonMuslim manufacturers in this country (Tieman, 2011). Its government attempts to create a nodal agency to promote Malaysia as a centre for Halal foods to cover Islamic dietary requirements (Muhammad et al., 2009). Regarding these contributions, Malaysian halal food companies have been chosen as a population in this study.

\section{MATERIALS AND METHODS}

A questionnaire was designed to collect the required data. It is divided in three sections. The first section deals with company background information, second asks about the important drivers of implementing GSC and finally third section deals with respondent background. To increase questionnaire reliability, a part of the questionnaires were developed based on the research of previous studies by Diabat and Govindan (2011); Paulraj (2009); Alvarez-Gil et al. (2007); Kassinis and Vafeas (2006); Ravi et al. (2005) and Simpson and Power (2005). It was also considered and developed from other sources in literature and previous empirical studies; with emphasizing on the GSC implementation drivers. Throughout questionnaire construction, discussions were held with three experts in the field of GSC practices implementation to check on clarity of the questions and the appropriateness of the proposed scale. 
Table 2. The possible drivers of GSC implementation in Halal food companies

\begin{tabular}{ll}
\hline Improve company performance & Improve quality \\
\hline E-logistics and environment & Marketing pressure \\
Desire to reduce waste & Desire to reduce cost \\
Stakeholders can encourage environmental strategy & Supply integration \\
Manage economic risk & Top management support \\
Pressure by environmental advocacy groups & Pressure from investors \\
Gaining competitive advantage & Potential for receiving publicity \\
Reduce risk of consumer criticism & Public pressure \\
Collaborate with customer & Pressure by customer to M \\
Collaborate with supplier & Legislative and regulatory compliance \\
Proactive action pre regulation & ISO 14000 certification \\
Non-economic stakeholders & \\
\hline
\end{tabular}

The comments and feedback given were very useful in enhancing, rectifying and improving the questionnaire. Based on their experiences some additional questions have been placed in the questionnaire. Second section of the questionnaire is included 23 items (Table 2). Each item represents a possible driver of implementing GSC practices in the halal food companies.

The questionnaire was distributed among 300 Halal food companies which participated in food festivals 2011 and 2012 that were held in Kuala Lumpur and Penang in Malaysia. These companies participated in these festivals from all over the Malaysia. In the case of reliability test, all the results proved the survey instrument have high internal consistency with Cronbach's alpha values $>0.80$ and therefore it is reliable.

\section{RESULTS AND DISCUSSION}

From 300 companies which questionnaire was distributed 61 usable answered were collected. The results of these questionnaire showed that the highest percentage of participants are small local c ompanies. These companies have less than 50 full time employees classified according to SMEcorp, 2012. Examining the results in more detail, it was found that according to chi-square test at the 0.05 confident level, sizes of companies has influence on implementing GSC practices in these companies. It means that with increasing the size of halal food companies the rate of GSC practices implementation is increased. It is interesting that type of ownership such as local, foreign and joint venture do not have any influence on implementing GSC in these companies.

According to these results less than $24 \%$ of halal food companies are implementing GSC practices. More than $50 \%$ of GSC companies are large local companies while $7.1 \%$ are small companies. These results confirm the results of previous studies (Shah and Ward, 2003) and show that large companies are more successful in implementing new quality systems. It is noteworthy that since non GSC companies do not have any experience in implementing GSC practices the results of this study focus on GSC companies.

In term of the quality certificate, results highlighted that $7.1 \%$ of GSC companies do not have any quality certificate. Since implementing GSC practices requires implementing some quality systems the reason behind this matter might be that these companies implement some quality systems that might be not mentioned in questionnaire items (Fig. 1) and in the questionnaire they did not mention which quality systems are implementing. $42.9 \%$ of GSC companies reported that they are implementing at least one quality system while only $7.1 \%$ of these companies have more than 4 quality certificates. The highest rate (more than 67\%) of GSC companies (Fig. 1) was certified by HACCP (Hazard Analysis Critical Control Point). This certificate addresses physical, chemical and biological hazards as a means of prevention rather than finished product inspection. The second rate (more than $32 \%$ ) of halal food companies was certified by ISO9001.This is a quality management system which designed to ensure companies that they meet customers' requirements. ISO 14000 standard specifically is related to environmental management which help companies to minimize the negative effect of their processes, operations and activities to the environment. So, it is expected that all halal food companies which reported they implemented GSC implement this quality system in their company. However, the results of this study do not meet this expectation and show that only $3.3 \%$ of GSC companies certified by ISO 14000 . The reasons behind this might be that these GSC companies are at the first stage of implementing green practices in their supply chain or they did not attempt to certify ISO 14000. So aside from HACCP which is necessary for food companies, Malaysian halal food companies did not attempt to apply other quality systems. Lack of understanding of quality systems and their benefits among Malaysian halal food companies and lack of financial support could be cause of these deficiencies. 
Mohd Nizam Ab Rahman et al. / American Journal of Environmental Science 9 (3): 240-246, 2013

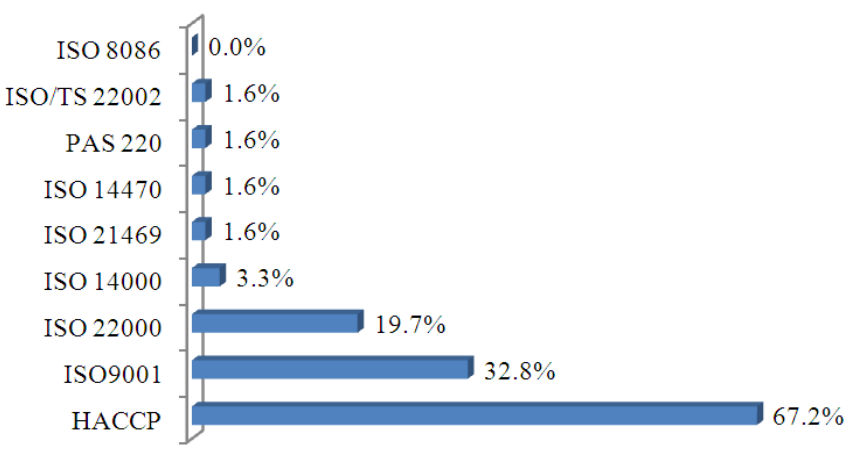

Fig. 1. Quality certificates of Halal food companies

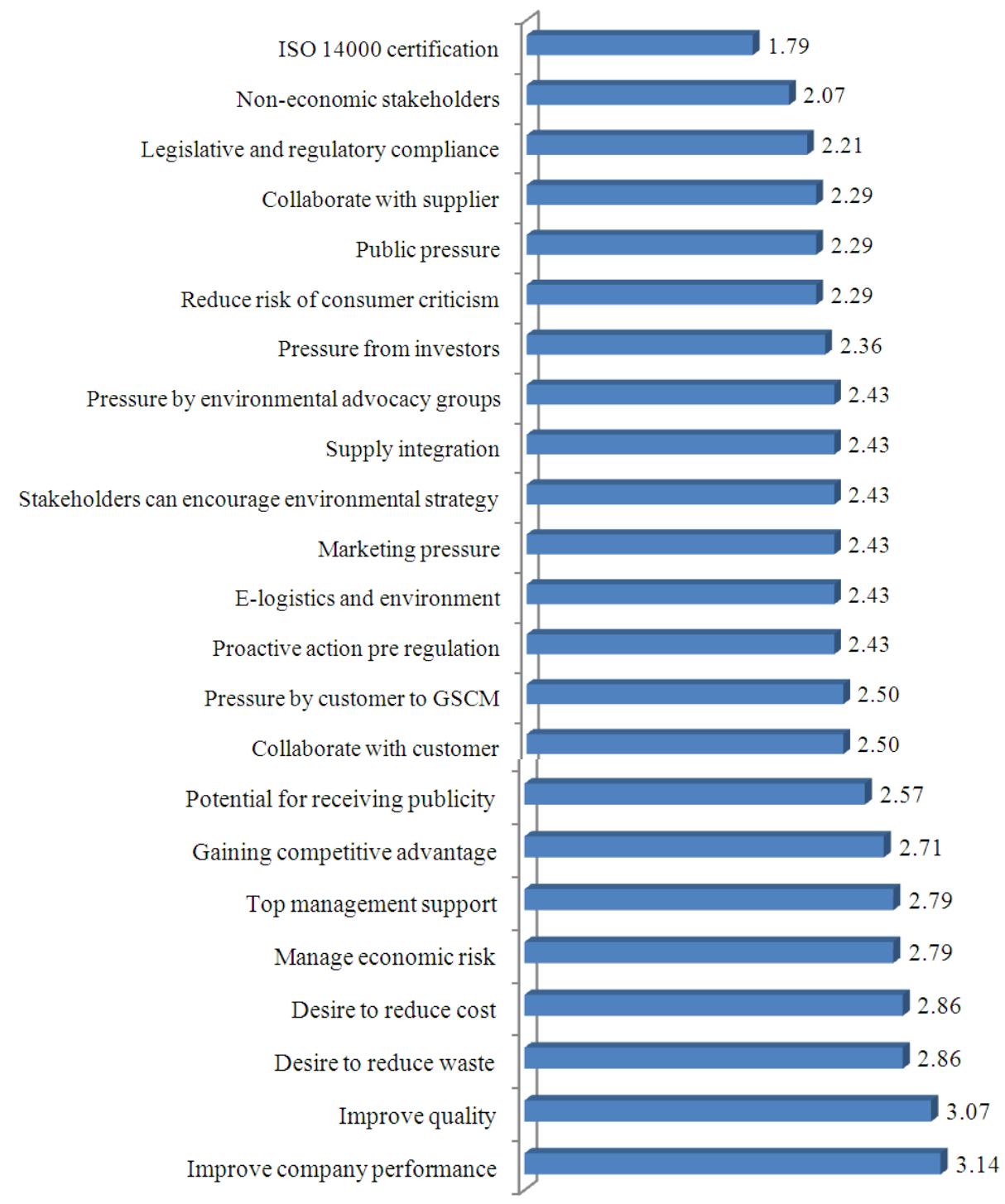

Fig. 2. Driver of GSC implementation in Halal Food Companies 
Halal food companies reported that the main driver which motivates them to move toward implementing GSC is improving company performance (Fig. 2). Quality improvement is highlighted as the second important driver of GSC implementation. Reducing costs and wastes are reported at the third level of importance. Khidir and Zailani (2009) conduct a study among other Malaysian companies and found out that they mostly motivated by social responsibility, company benefits and customers requirements as important drivers of GSC implementation. Examining the results in more detail, important drivers in halal food companies is similar to other Malaysian companies because halal food companies focus on their company benefits when they put emphasis on improving company performance and reduce costs and wastes. Although the focal point of Malaysian mainly is their internal benefits instead of environmental issues, the aim of green practices can be achieved by reducing wastes and improving quality in these companies. Decreasing wastes and improving quality mean using less raw materials and energy in these companies which are the important objectives of green practices.

There is no doubt that in the today fierce global market; being competitive has the critical role in surviving a company. So it is not surprising that why halal food companies are motivated by some drivers such as managing economic risk, gaining competitive advantages and receiving publicity at the high level (Fig. 2) in implementing GSC. Many customers prefer to buy green products in the market, so those products that have green label are in the priority for customers. Hence in the supply chain each company as a customer of other companies force their suppliers to move toward green practices to gain competitive advantages (Alvarez-Gil et al., 2007; Rao, 2006; Simpson and Power, 2005).

The most striking result to emerge from the data is that the least important driver of GSC implementation in halal food companies is ISO 14000 certificate. This certificate helps companies to manage their process and activities regarding the least harm to the environment, so it should be the strong motive for those companies that intend to adopt GSC practices. Therefore it is surprising that why halal food companies put it at the lowest level. It can be the results of lack of understanding of the ISO 14000 standard and green practices among these companies. It indicates that they are at the first stage of adopting GSC. The results of a study in India revealed that in those companies that are successful in implementing GSC, ISO 14000 certificate is the second important driver to adopt GSC practices (Diabat and Govindan, 2011).

Further analysis showed that according to chi-square test at the 0.05 confident levels size of companies does not have any influence on GSC drivers. It implies that these drivers are not related to the company's size. The same results have been achieved when the influence of company's ownership on the GSC drivers was studied. It means that whether the owner of the company is local, foreign or joint venture, they are motivated from the same drivers in implementing GSC. However this is noteworthy that halal food companies put emphasis on the top management support as one of the main driver of GSC implementation. This indicated that although halal food companies are at the first stage of GSC implementation and many of them did not adopt yet, their top managers are aware of the importance of implementing green practices in their companies.

\section{CONCLUSION}

The rate of GSC implementation among Malaysian halal food companies is not satisfactory because less than $24 \%$ of these companies are implementing GSC. The results highlight that similar to implementing other quality systems, implementing GSC is highly depended on the company's size and large companies are more successful in implementation. Besides, the results indicated that those companies which are implementing GSC are at the first stage of GSC implementation. So it is strongly suggested that these companies benchmark from other successful companies either in the Malaysia or external companies to more understand GSC concept and practices.

According to this study, internal drivers such as quality improvement and cost reduction more motivated halal food companies in adopting GSC instead of environment benefits. However since these drivers mostly focus on the wastes reduction and performance improvement, they can fulfil environmental needs. It is interesting that although halal food companies are not fully successful in implementing GSC, they understand its advantages and realize that they will be competitive in the fierce market with implementing GSC. Moreover, it is a valuable understanding that their customers are intended to move toward GSC, so they highlight customer satisfaction as important driver of adopting GSC. In implementing each new system, top manager support is the most important factor. Since halal food 
companies reported manager support as the main driver of GSC implementation, it can be concluded that in the near future they will be very successful in adopting GSC practices. Top manager support can overcome many barriers and problems in implementing GSC. For instance many requirements such as new equipments, skilled worker and finance can be provided easily with supporting top managers.

\section{REFERENCES}

Alvarez-Gil, M.J., P. Berrone, F.J. Husillos and N. Lado, 2007. Reverse logistics, stakeholders' influence, organizational slack and managers' posture. J. Bus. Res., 60: 463-473. DOI: 10.1016/j.jbusres.2006.12.004

Beamon, B.M., 1999. Designing the green supply Chain. Logist. Inform. Manage., 12: 332-342. DOI: 10.1108/09576059910284159

Bowen, F.E., P.D. Cousins, R.C. Lamming and A.C. Faruk, 2001. Horses for courses: Explaining the gap between the theory and practice of green supply. Greener Manage. Int., 35: 41-60.

Diabat, A. and K. Govindan, 2011. An analysis of the drivers affecting the implementation of green supply chain management. Resou. Conserv. Recycl., 55: 659-667. DOI: 10.1016/j.resconrec.2010.12.002

Geyer, R. and T. Jackson, 2004. Supply loops and their constraints: The industrial ecology of recycling and reuse. Emerald Manage. Rev., 45: 55-73.

Holt, D. and A. Ghobadian, 2009. An empirical study of green supply chain management practices amongst UK manufacturers. J. Manufact. Technol. Manage., 20: 933-56. DOI: 10.1108/17410380910984212

Ismail, A.R., 2010. A survey on environmental factors and job satisfaction among operators in automotive industry. Am. J. Applied Sci., 7: 556-561. DOI: 10.3844/ajassp.2010.556.561

Jorgensen, F., R. Matthiesen, J. Nielsen and J. Johansen, 2007. Lean maturity, lean sustainability. Int. Federat. Inform. Precess., 246: 371-378. DOI: 10.1007/978-0-387-74157-4_44

Kassinis, G. and N. Vafeas, 2006. Stakeholder pressures and environmental performance. Acad. Manage. J., 49: 145-159. DOI: 10.5465/AMJ.2006.20785799

Khidir, T.A. and S. Zailani, 2009. Going green in supply chain towards environmental sustainability. Global J. Environ. Res., 3: 246-251.
Kumaran, G.S., N. Mushule and M. Lakshmipathy, 2008. A review on construction technologies that enables environmental protection: Rubberized concrete. Am. J. Eng. Applied Sci., 1: 40-44. DOI: 10.3844/ajeassp.2008.40.44

Lefebvre, E., L.A. Lefebvre and S. Talbot, 2003. Determinants and impacts of environmental performance in SMEs. R\&D Manage., 33: 263-283. DOI: $10.1111 / 1467-9310.00297$

Manzouri, M., M.N.A. Rahman and H. Arshad, 2011. Order management in Supply Chain: A case study in automotive companies. Am. J. Eng. Applied Sci., 4, 372-379. DOI: 10.3844/ajeassp.2011.372.379

Mentzer, J.T., W. DeWitt, J.S. Keebler, S. Min and N.W. Nix et al., 2001. Defining supply chain management. J. Bus. Logist., 22: 1-25. DOI: 10.1002/j.2158-1592.2001.tb00001.x

Muhammad, N.M.N., F.M.D Isa and B.C. Kifli, 2009. Positioning Malaysia as halal-hub: Integration role of supply Chain strategy and halal assurance system. Asian Soc. Sci., 5: 44-52.

Paulraj, A., 2009. Environmental motivations: A classification scheme and its impact on environmental strategies and practices. Bus. Strategy Environ., 18: 453-68. DOI: 10.1002/bse.612

Rao, P. and D. Holt, 2005. Do green supply chains lead to competitiveness and economic performance. Int. J. Operat. Product. Manage., 25: 898-916. DOI: $10.1108 / 01443570510613956$

Rao, P., 2002. Greening the supply chain: A new initiative in South East Asia. Int. J. Operat. Product. Manage., 22: 632-655. DOI: $10.1108 / 01443570210427668$

Rao, P., 2006. Greening of Suppliers/in-Bound Logistics in the South East Asian Context. In: Greening the Supply Chain, Sarkis, J. (Ed.), Springer, London, ISBN-10: 1846282985, pp: 189-204.

Ravi, V., R. Shankar and M.K. Tiwari, 2005. Productivity improvement of a computer hardware supply chain. Int. J. Product. Perform. Manage., 54: 239-255. DOI: 10.1108/17410400510593802

Rhee, S.S.K. and S.Y. Lee, 2003. Dynamic change of corporate environmental strategy: Rhetoric and reality. Bus. Strategy Environ., 12: 175-190. DOI: 10.1002/bse. 356

Saridogan, M., 2012. The impact of green supply Chain management on transportation cost reduction in Turkey. Int. Rev. Manage. Market., 2: 112-121. 
Sarkis, J., 1998. Evaluating environmentally conscious business practices. Eur. J. Operat. Res., 107: 159-174. DOI: 10.1016/S0377-2217(97)00160-4

Shah, R. and P.T. Ward, 2003. Lean manufacturing: Context, practice bundles and performance. J. Operat. Manage., 21: 129-149. DOI: 10.1016/S0272-6963(02)00108-0

Simpson, D.F. and D.J. Power, 2005. Use the supply relationship to develop lean and green suppliers. Supply Chain Manage.: Int. J., 10: 60-68. DOI: $10.1108 / 13598540510578388$

Tieman, M., 2011. The application of Halal in supply chain management: In-depth interviews. J. Islamic Market., 2: $\quad$ 186-195. DOI: $10.1108 / 17590831111139893$

Vachon, S. and R.D. Klassen, 2006. Extending green practices across the supply chain: The impact of upstream and downstream integration. Int. J. Operat. Product. Manage., 26: 795-821. DOI: 10.1108/01443570610672248

Vachon, S., 2007. Green supply chain practices and the selection of environmental technologies. Int. J. Product. Res., 45: 4357-79. DOI: 10.1080/00207540701440303

Vijaya, S., A.N. Ma and Y.M. Choo, 2009. A gate to gate assessment of environmental performance for production of crude palm kernel oil using life cycle assessment approach. Am. J. Environ. Sci., 5: $267-$ 272. DOI: 10.3844 /ajessp.2009.267.272
Wells, P. and M. Seitz, 2005. Business models and closed-loop supply chains: A typology. Supply Chain Manage.: Int. J., 4: 249-251. DOI: 10.1108/13598540510612712

Williamson, D., G. Lynch-Wood and J. Ramsay, 2006. Drivers of environmental behaviour in manufacturing SMEs and the implications for CSR. J. Bus. Ethics, 67: 317-330. DOI: 10.1007/s10551006-9187-1

Zhu, Q., J. Sarkis and K.H. Lai, 2007b. Initiatives and outcomes of green supply chain management implementation by Chinese manufacturers. J. Environ. Manage., 85: 179-89. DOI: 10.1016/j.jenvman.2006.09.003

Zhu, Q., J. Sarkis and K.H. Lai, 2008. Green supply chain management implications for "closing the loop". Transport. Res., 44: 1-18. DOI: 10.1016/j.tre.2006.06.003

Zhu, Q., J. Sarkis and L.K. Sarkis, 2007a. Green supply chain management: Pressures, practices and performance within the Chinese automobile industry. J. Cleaner Product., 15: 1041-52. DOI: 10.1016/j.jclepro.2006.05.021

Zhu, Q., J. Sarkis, J.J. Cordeiro and K.H. Lai, 2003. Firm-level correlates of emergent green supply chain management practices in the Chinese context. Omega, 36: 577-91. DOI: 10.1016/j.omega.2006.11.009 